\title{
A Systematic Review and Research Agenda of Portrayal of Cities in Select Indian English Fiction: Neti Neti: Not This, Not This by Anjum Hasan, The Lives of Others by Neel Mukherjee and Chennaivaasi by T. S. Tirumurti
}

\author{
Bharathi H. Prabhu ${ }^{1}$ \& Lourdusamy A. ${ }^{2}$ \\ ${ }^{1}$ Research Scholar, College of Social Sciences \& Humanities, Srinivas University, \\ Mangaluru, India. \\ ORCID ID: 0000-0001-5260-5210; Email: bharathi.cssh@ srinivasuniversity.edu.in \\ ${ }^{2}$ Research Professor, College of Social Sciences \& Humanities, Srinivas University, \\ Mangaluru, India. \\ Orcid ID: 0000-0002-9011-6212; E-mail: swamysac@gmail.com
}

Area/Section: English Literature.

Type of the Paper: Content analysis and exploratory study.

Type of Review: Peer Reviewed as per $|\mathrm{C}| \mathrm{O}|\mathrm{P}| \mathrm{E} \mid$ guidance.

Indexed in: OpenAIRE.

DOI: https://doi.org/10.5281/zenodo.6320687

Google Scholar Citation: IJMTS

\section{How to Cite this Paper:}

Prabhu, Bharathi H., \& Lourdusamy, A., (2022). A Systematic Review and Research Agenda of Portrayal of Cities in Select Indian English Fiction: Neti Neti: Not This, Not This by Anjum Hasan, The Lives of Others by Neel Mukherjee and Chennaivaasi by T. S. Tirumurti. International Journal of Management, Technology, and Social Sciences (IJMTS), 7(1), 184-209. DOI: https://doi.org/10.5281/zenodo.6320687

International Journal of Management, Technology, and Social Sciences (IJMTS) A Refereed International Journal of Srinivas University, India.

CrossRef DOI: https://doi.org/10.47992/IJMTS.2581.6012.0185

(C) With Author.

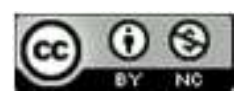

This work is licensed under a Creative Commons Attribution-Non-Commercial 4.0 International License subject to proper citation to the publication source of the work.

Disclaimer: The scholarly papers as reviewed and published by the Srinivas Publications (S.P.), India are the views and opinions of their respective authors and are not the views or opinions of the SP. The SP disclaims of any harm or loss caused due to the published content to any party. 


\title{
A Systematic Review and Research Agenda of Portrayal of Cities in Select Indian English Fiction: Neti Neti: Not This, Not This by Anjum Hasan, The Lives of Others by Neel Mukherjee and Chennaivaasi by T. S. Tirumurti
}

\author{
Bharathi H. Prabhu ${ }^{1} \&$ Lourdusamy A. ${ }^{2}$ \\ ${ }^{1}$ Research Scholar, College of Social Sciences \& Humanities, Srinivas University, \\ Mangaluru, India. \\ ORCID ID: 0000-0001-5260-5210; Email: bharathi.cssh@srinivasuniversity.edu.in \\ ${ }^{2}$ Research Professor, College of Social Sciences \& Humanities, Srinivas University, \\ Mangaluru, India. \\ Orcid ID: 0000-0002-9011-6212; E-mail: swamysac@gmail.com
}

\begin{abstract}
Purpose: Cities have always found a place in novels, as a setting which wields influence. Much great writing across cultures has been devoted to figuring out this intangible, yet resolute influence. The city is definitely an agent of transformation in many English works of fiction and this paper highlights the works of researchers who have examined the various ways in which cities are being foregrounded to offer them prominence in the narration and make them significant players in the overall presentation. The impact on the lives of the characters, plot and narration of the novels due to the spatial and cultural ethos of the city, the ways in which the city is portrayed and the reflection of this on the reader form the gist of the findings of the research

Design/Methodology/Approach: The review of literature is carried out using information from various online open access sources such as peer-reviewed journals, doctoral theses, websites and a range of portals such as Google Scholar.

Findings/Result: Optimizing the reading experience to help the reader move beyond a superficially touristy perspective of the space used as a setting and engage with the city's complex social, political, historical, and cultural milieu requires a deeper study of the different ways in which the city can be foregrounded in novels.

Originality/Value: This paper examines the phenomenon of the projection of space in novels and memoirs. A novel concept of the author as a literary cartographer, who makes the work of fiction come alive by not only describing the city as text but also going beyond to offer maps as an aid to the narration and in the process enriching the total reader experience, is presented. Different ways in which the city has been melded into the novel, touching upon its history, architecture and cultural aspects so as to be a significant part of the narrative and wield influence, have been identified.
\end{abstract}

Paper Type: Content analysis and exploratory study.

Keywords: City in Novels, Sense of Place, City in Literature, Spatiality, Literary Cartographer

\section{INTRODUCTION :}

Projecting a cityscape as a compelling presence in a novel is a time-tested tool that has always enriched the reading experience for the reader. It adds a dimension to the novel that enables the reader to envision the narration with potency. Cityscapes serve as backdrops for writers who seek to provide authenticity and local flavours to explore themes such as suspense, crime, loneliness, even espionage, romance and excitement. All great cities have interesting histories that are many a time beyond the pale of the most creative imagination of writers. These histories shape the cultural ethos of the cities and provide perspectives that the writer may employ to add substance to the novel and increase the recall value. No doubt the city has always been a crucial aspect of literature, especially fiction and in that genre, specifically in novels. What is interesting is that even as it is accepted as being a significant player in 
the narrative process, novelists are going beyond making it a static setting and are now bringing cities to the forefront and imbuing them with relevance in the plot and characterisation of the main characters. This review of literature strives to delve into the ways in which novelists of world literature have foregrounded cities in a manner that makes the setting, in this case the cityscapes, a significant aspect of the plot, characterisation and narrative techniques.

\section{OBJECTIVES :}

The paper is a literature review of the research proposal - Portrayal of cities in select Indian English fiction: Neti Neti: Not This Not This by Anjum Hasan, The Lives of Others by Neel Mukherjee and Chennaivaasi by T. S. Tirumurti. It seeks to bring out issues and concerns around the theme and progresses to analyse the various aspects of the concept.

(1) To review the contributions of various researchers to the study of the portrayal of cities in novels.

(2) To learn various issues related to the projection of cities in novels.

(3) To determine the research gap after studying the literature.

(4) To develop a research agenda and provide a proposal for research progress.

(5) To propose an area of research study.

\section{METHODOLOGY OF DATA COLLECTION :}

The proposed research will be a content analysis and exploratory study. The selected research agenda for this work of scholarly research is a study of peer-reviewed articles, theses and books on the topic and an in-depth study of the primary works that are considered for the research. The focus will be on the primary texts and their contribution to the portrayal of cities in fiction, because novels most certainly have the potential to explore the many twists and turns of the plot and present narrative details. They also have the freedom to flesh out characters with backstories and can place significant focus on secondary characters that factor into the novel's plotlines. Short stories may lack that bandwidth. Hence, novels.

The primary texts will be studied for the ways in which they answer questions with regard to satisfying the objectives of the research. A comparative analysis would also be done on the ability of each text to offer solutions to the research objectives. A literary theory would be adopted as a prism through which the texts would be examined. Such a method, it is believed, provides valuable cultural and historical inputs as well as insights into complex models of human thought and language use.

\section{RELATED WORKS :}

Table 1 summarises the contributions of various authors who have analysed the ways in which cities as well as other spaces and places have been portrayed in fiction, mostly novels, so as to have an impact on the characters, plot and narration.

Table 1: Summary of findings with focus of discussion

\begin{tabular}{|c|l|l|l|}
\hline Sl. No & \multicolumn{1}{|c|}{ Title } & \multicolumn{1}{|c|}{ Focus } & Reference \\
\hline 1 & $\begin{array}{l}\text { Place attachment } \\
\text { and continuity of } \\
\text { urban place identity }\end{array}$ & $\begin{array}{l}\text { The author speaks about the connection } \\
\text { between aspects of architectural design, } \\
\text { characteristics and usability factor, and the } \\
\text { identity of the place that residents have created } \\
\text { in their minds. Upon a research backed by } \\
\text { survey tools in the shopping areas of Kuala } \\
\text { Lumpur, she tells us that constructs of place } \\
\text { attachment can influence urban planners. This } \\
\text { in turn sustains the momentum of tourist } \\
\text { attraction and retention of footfall in the city. }\end{array}$ & \\
\hline
\end{tabular}




\begin{tabular}{|c|c|c|c|}
\hline 2 & $\begin{array}{l}\text { The city novel: } \\
\text { Measuring } \\
\text { referential, spatial, } \\
\text { linguistic and } \\
\text { temporal distances }\end{array}$ & $\begin{array}{l}\text { Novels based on cities emphasise distances - } \\
\text { these may be between actual spaces or } \\
\text { imagined ones. The protagonists of the novel } \\
\text { also cover distances and these too may be } \\
\text { pointed out in reference to their memories } \\
\text { connected to the places. }\end{array}$ & $\begin{array}{l}\text { Ameel, L. } \\
(2017)[6]\end{array}$ \\
\hline 3 & $\begin{array}{l}\text { From the city of } \\
\text { London to the } \\
\text { desert island : } \\
\text { Daniel Defoe and } \\
\text { the writing of space } \\
\text { and places }\end{array}$ & $\begin{array}{l}\text { Geographic locations form the life of the novel } \\
\text { based on the connections they have with the } \\
\text { characters inhabiting the novel. The distinctive } \\
\text { characteristics of the places reflect the inner } \\
\text { turmoil of the characters. }\end{array}$ & $\begin{array}{l}\text { Peraldo, E. } \\
(2017)[7]\end{array}$ \\
\hline 4 & $\begin{array}{l}\text { The speculative } \\
\text { fictional mapping } \\
\text { of literary } \\
\text { Johannesburg's } \\
\text { spaces in Beukes' } \\
\text { Zoo City and } \\
\text { Grey's The Mall }\end{array}$ & $\begin{array}{l}\text { The emotional world of the characters is } \\
\text { mapped in consonance with the city's } \\
\text { dysfunctional social spaces. Johannesburg, a } \\
\text { city with a vibrant social life, is shown up in } \\
\text { ways that reflect its fall side. The spaces of } \\
\text { criminality are evident and the manipulative } \\
\text { aspects of consumption culture are } \\
\text { foregrounded. }\end{array}$ & $\begin{array}{l}\text { Manase, I. } \\
(2017)[8]\end{array}$ \\
\hline 5 & $\begin{array}{l}\text { The production of } \\
\text { alternative global } \\
\text { spaces: Walking in } \\
\text { the city in Salman } \\
\text { Rushdie's novels }\end{array}$ & $\begin{array}{l}\text { Rushdie adopts the allegory of walking in the } \\
\text { city to reflect the protagonist's attitude of } \\
\text { resistance. }\end{array}$ & $\begin{array}{l}\text { Roy, M., et al. } \\
(2018)[9]\end{array}$ \\
\hline 6 & $\begin{array}{l}\text { Crafting 'Literary } \\
\text { sense of place': The } \\
\text { generative work of } \\
\text { literary place- } \\
\text { making }\end{array}$ & $\begin{array}{l}\text { A significant aspect of the connectedness of } \\
\text { literature and place has yet to receive attention } \\
\text { from critics: the ways in which writers create } \\
\text { literary places. Writers do not only show the } \\
\text { place: they also create it. }\end{array}$ & $\begin{array}{l}\text { Mundell, M. } \\
\text { (2018) [10] }\end{array}$ \\
\hline 7 & $\begin{array}{l}\text { Crossing the street: } \\
\text { Literature and } \\
\text { urban space }\end{array}$ & $\begin{array}{l}\text { This paper looks at how the city is represented } \\
\text { in contemporary literature; it analyses cultural } \\
\text { symbols through the lived spaces of the city, be } \\
\text { it graffiti, other forms of street art or even the } \\
\text { simple act of walking in the city. It thus enables } \\
\text { the reader to come on board towards an analysis } \\
\text { of literary symbolism with regard to the city } \\
\text { that houses the characters in the writing. }\end{array}$ & $\begin{array}{l}\text { Bryden, I. } \\
(2009)[11]\end{array}$ \\
\hline 8 & $\begin{array}{l}\text { Exploring } \\
\text { Thirdspace in Nada } \\
\text { Awar Jarrar's } \\
\text { Unsafe Haven }\end{array}$ & $\begin{array}{l}\text { The author examines the ambivalence of the } \\
\text { migrant in relation to Beirut. While the } \\
\text { characters in the story strive to make sense of } \\
\text { life in a war zone, they attempt to create their } \\
\text { own worlds in a haze of nostalgia, for the state } \\
\text { of things as they were, on the lines of Edward } \\
\text { Soja's concept of third space. }\end{array}$ & $\begin{array}{l}\text { Balaa, L. } \\
(2018) .(2007) \\
{[12]}\end{array}$ \\
\hline 9 & $\begin{array}{l}\text { New York and } \\
\text { Toronto novels } \\
\text { after } \\
\text { postmodernism: } \\
\text { Explorations of the } \\
\text { urban by Caroline } \\
\text { Rosenthal (review) }\end{array}$ & $\begin{array}{l}\text { This is a review of the book by Rosenthal in } \\
\text { which the reviewer examines how the } \\
\text { characters in four novels, which have Toronto } \\
\text { and New York as settings, negotiate the rigours } \\
\text { of living in these cities and narrate stories of } \\
\text { their urban experiences. }\end{array}$ & $\begin{array}{l}\text { Minto, D. N. } \\
(2015)[13]\end{array}$ \\
\hline 10 & $\begin{array}{l}\text { Mapping the } \\
\text { modern city: Alan }\end{array}$ & $\begin{array}{l}\text { The authors give us a bird's eye view of the way } \\
\text { Sillitoe's novels, in which the setting is }\end{array}$ & $\begin{array}{l}\text { Daniels, S., et } \\
\text { al. (1993) [14] }\end{array}$ \\
\hline
\end{tabular}




\begin{tabular}{|c|c|c|c|}
\hline & $\begin{array}{l}\text { Sillitoe's } \\
\text { Nottingham novels }\end{array}$ & $\begin{array}{l}\text { Nottingham, use maps to offer a visual } \\
\text { explanation of the development of the novel's } \\
\text { plot. Readings of maps are a delightful part of } \\
\text { the works of Sillitoe. }\end{array}$ & \\
\hline 11 & $\begin{array}{l}\text { The image of the } \\
\text { city in the novels of } \\
\text { Italo Calvino }\end{array}$ & $\begin{array}{l}\text { The writer tells us that Calvino has motivated } \\
\text { readers, from across continents, to reimagine } \\
\text { cities, mythology and travel so as to transform } \\
\text { our perception of them. Two of his works are } \\
\text { analysed for being timeless odes to the travails } \\
\text { of migrating to the city. }\end{array}$ & $\begin{array}{l}\text { Cannon, J. } \\
\text { (1978) [15] }\end{array}$ \\
\hline 12 & $\begin{array}{l}\text { Imaginary places in } \\
\text { literature that } \\
\text { became iconic }\end{array}$ & $\begin{array}{l}\text { The author makes a case for fictional cities in } \\
\text { novels that have caught the imagination of the } \\
\text { readers and become much loved, so much so } \\
\text { that a few like of RK Narayan's Malgudi have } \\
\text { been recreated in TV serials that are telecast } \\
\text { regularly and Hogwarts of Harry Potter fame } \\
\text { has become a cult classic and tourist attraction } \\
\text { in amusement parks worldwide. }\end{array}$ & $\begin{array}{l}\text { Features (2015) } \\
{[16]}\end{array}$ \\
\hline 13 & $\begin{array}{l}\text { Salman Rushdie's } \\
\text { Cities: } \\
\text { Reconfigurational } \\
\text { politics and the } \\
\text { contemporary } \\
\text { urban imagination }\end{array}$ & $\begin{array}{l}\text { The writer views Rushdie's treatment of his } \\
\text { cities through the lens of history as well as } \\
\text { contemporary functioning and mentions that } \\
\text { Rushdie's cities of exile have protagonists who } \\
\text { might want to live in a cocoon that typifies the } \\
\text { places from which they migrated. The cities } \\
\text { seem to merge into each other and at times to } \\
\text { transform each other too. }\end{array}$ & $\begin{array}{l}\text { Parashkevova, } \\
\text { V. (2012) [17] }\end{array}$ \\
\hline 14 & $\begin{array}{l}\text { This Dasht-e- } \\
\text { Tanhaii called the } \\
\text { planet earth: The } \\
\text { metamorphosis of } \\
\text { space and identity in } \\
\text { Nadeem Aslam's } \\
\text { Maps for Lost } \\
\text { Lovers }\end{array}$ & $\begin{array}{l}\text { There is a mutually dependent and cathartic } \\
\text { relationship between space on one hand and } \\
\text { identity on the other. Many contemporary } \\
\text { British Asian novels that are about the diasporic } \\
\text { experience focus on and enrich our } \\
\text { understanding of this relationship through their } \\
\text { descriptions of the newly adopted cities of the } \\
\text { settlers and the ways in which the characters } \\
\text { respond to the cultures of the cities. } \\
\text { Displacement is a sure-fire walk to loneliness, } \\
\text { for the displaced. }\end{array}$ & $\begin{array}{l}\text { Pataki, É. (2014) } \\
\text { [18] }\end{array}$ \\
\hline 15 & $\begin{array}{l}\text { Geocriticism: Real } \\
\text { and fictional spaces }\end{array}$ & $\begin{array}{l}\text { The author proceeds to offer the reader a } \\
\text { spatiological inventory in line with Lefebvre's } \\
\text { thoughts about space. He introduces the } \\
\text { chapters of his book, wherein he backs his } \\
\text { chapters taking recourse to Bakhtin and Yi-Fu } \\
\text { Tuan's perspective on the concept of space. Our } \\
\text { impressions of a place are a sum total of not } \\
\text { only our personal experiences with it, but also } \\
\text { our reading about another's experiences, and } \\
\text { our biases that form our perspectives. }\end{array}$ & $\begin{array}{l}\text { Westphal, B. } \\
\text { (2011) [25] }\end{array}$ \\
\hline 16 & $\begin{array}{ll}\text { Place names } & \text { as } \\
\text { ingredients } & \text { of } \\
\text { space-related } & \\
\text { identity } & \end{array}$ & $\begin{array}{l}\text { The article concerns itself with the role of the } \\
\text { names of places in the formation of identity. } \\
\text { The author highlights the fact that the culture of } \\
\text { a social group and geographical space is closely } \\
\text { intertwined. The place may have taken its name } \\
\text { from the topography or its history and the } \\
\text { society around and these names create ties } \\
\text { among members of the society. }\end{array}$ & $\begin{array}{l}\text { Jordan, P. } \\
(2012)[26]\end{array}$ \\
\hline
\end{tabular}




\begin{tabular}{|c|c|c|c|}
\hline 17 & $\begin{array}{l}\text { Geocritical } \\
\text { explorations: } \\
\text { Space, place, and } \\
\text { mapping in literary } \\
\text { and cultural studies }\end{array}$ & $\begin{array}{l}\text { In his introduction to the collection, Tally is } \\
\text { emphatic in his assertion that space has found } \\
\text { its niche in literary creations and analysis too. } \\
\text { While earlier it was time that provided the } \\
\text { framework for literary works, it is now space } \\
\text { that occupies centre stage. He reaffirms } \\
\text { Westphal's opinion that geocriticism falls } \\
\text { somewhere between real and imagined } \\
\text { geographies and needs to be explored further by } \\
\text { literary critics. }\end{array}$ & $\begin{array}{l}\text { Tally Jr, R. T. } \\
(\text { Ed.) (2011) } \\
{[27]}\end{array}$ \\
\hline 18 & $\begin{array}{l}\text { Geocriticism: } \\
\text { Reading literature } \\
\text { in the spatial tur }\end{array}$ & $\begin{array}{l}\text { This paper brings up critical questions and } \\
\text { significant issues pertaining to territorially- } \\
\text { oriented writings of fiction. The author asks if } \\
\text { Geographic Information Systems (GIS) can be } \\
\text { used a tool to help the reader visualize literary } \\
\text { texts. }\end{array}$ & $\begin{array}{l}\text { Al-Khafaji, A. } \\
\text { (2018) [28] }\end{array}$ \\
\hline 19 & $\begin{array}{l}\text { Literature, } \\
\text { geography, and the } \\
\text { postmodern poetics } \\
\text { of place }\end{array}$ & $\begin{array}{l}\text { The book has the objective of helping us to see } \\
\text { how literary representations support us to } \\
\text { examine and understand space. The focus is on } \\
\text { literary as well as other mediums such as plays } \\
\text { and movies too, of the late twentieth century } \\
\text { and beyond. }\end{array}$ & $\begin{array}{l}\text { Prieto, E. (2012) } \\
\text { [29] }\end{array}$ \\
\hline 20 & $\begin{array}{l}\text { Cities of tomorrow- } \\
\text { urban landscapes } \\
\text { and urban } \\
\text { sustainability in } \\
\text { Marie Lu's Legend } \\
\text { trilogy }\end{array}$ & $\begin{array}{l}\text { The researcher looks at the ways in which cities } \\
\text { are portrayed in the young adult series which } \\
\text { can be termed as dystopian fiction, which takes } \\
\text { place in Los Angeles. The inequity of the } \\
\text { distribution of wealth in cities is foregrounded } \\
\text { profoundly and the writer gives us three types } \\
\text { of urban scenarios - realistic, futuristic and } \\
\text { contrasted in terms of economic disparities. The } \\
\text { realistic represents the urban geography almost } \\
\text { true to existing detail, while the futuristic is a } \\
\text { fantasy land of sorts. The writer hopes to nudge } \\
\text { readers towards looking at cities from the } \\
\text { perspective of urban sustainability. }\end{array}$ & $\begin{array}{l}\text { Hodneland, T. } \\
\text { E. (2019) [30] }\end{array}$ \\
\hline 21 & $\begin{array}{l}\text { Geocriticism, } \\
\text { geopoetics, } \\
\text { geophilosophy, and } \\
\text { beyond }\end{array}$ & $\begin{array}{l}\text { The author offers a theoretical base for the } \\
\text { literary analysis of space. He brings up the } \\
\text { phenomenological viewpoint that asks us to } \\
\text { see the subjective meaning of space and moves } \\
\text { on towards the poststructural that questions } \\
\text { this subjective representation. He then brings } \\
\text { up activism and environmentalism. }\end{array}$ & $\begin{array}{l}\text { Prieto, E. (2011) } \\
\text { [31] }\end{array}$ \\
\hline 22 & $\begin{array}{l}\text { Rethinking space: } \\
\text { An outsider's view } \\
\text { of the spatial turn }\end{array}$ & $\begin{array}{l}\text { The author takes a look at social production of } \\
\text { spatiality as a critical theory. Considering the } \\
\text { spatial turn in literary studies, this paper makes } \\
\text { a study of Lima, Peru in the latter part of 18th } \\
\text { century, to understand the interplay of colonial } \\
\text { rule and its impacts on the formation of } \\
\text { identities. Space is seen as a combination of } \\
\text { circumstances and geography that resulted in } \\
\text { the formation of a social order. }\end{array}$ & $\begin{array}{l}\text { Arias, S. (2010) } \\
\text { [32] }\end{array}$ \\
\hline 23 & $\begin{array}{l}\text { Deep locational } \\
\text { criticism: } \\
\text { Imaginative place }\end{array}$ & $\begin{array}{l}\text { The spatial turn in literary analysis that sprung } \\
\text { up in the 1990s is the precursor to this book that } \\
\text { looks at how to learn as well as convey to } \\
\text { students the relationship that exists between the }\end{array}$ & $\begin{array}{l}\text { Finch, J. (2016) } \\
\text { [33] }\end{array}$ \\
\hline
\end{tabular}




\begin{tabular}{|c|c|c|c|}
\hline & $\begin{array}{l}\text { in literary research } \\
\text { and teaching }\end{array}$ & $\begin{array}{l}\text { presentation of location and the text. Various } \\
\text { genres of fiction such as drama, poetry and } \\
\text { television, considered to be realistic, are } \\
\text { presented as illustrations. }\end{array}$ & \\
\hline 24 & $\begin{array}{l}\text { Literary } \\
\text { cartographies: } \\
\text { Spatiality, } \\
\text { representation, and } \\
\text { narrative }\end{array}$ & $\begin{array}{l}\text { This book has a series of articles that explore } \\
\text { mapping as a narrative device in well- known } \\
\text { novels ranging from Ulysses to Don Quixote } \\
\text { and Mill on the Floss. The writers show us how } \\
\text { these literary works are rooted in settings that } \\
\text { represent the social milieus of their times. }\end{array}$ & $\begin{array}{l}\text { Tally Jr, R. T. } \\
\text { (Ed.) (2016) } \\
{[34]}\end{array}$ \\
\hline 25 & $\begin{array}{l}\text { Searching for the } \\
\text { dear green place in } \\
\text { Agnes Owens's } \\
\text { Like Birds in the } \\
\text { Wilderness }\end{array}$ & $\begin{array}{l}\text { The author uses the phrase 'dear green place' as } \\
\text { a metaphor to bring out word pictures of the } \\
\text { western parts of Scotland. The protagonist } \\
\text { leaves his hometown, but finds that he cannot } \\
\text { obliterate the images of his hometown and is } \\
\text { subconsciously seeking it wherever he goes. } \\
\text { Different landscapes and cityscapes are } \\
\text { described and the realisation is that the dear } \\
\text { green place is a space he can create wherever he } \\
\text { goes, in his own mind. }\end{array}$ & $\begin{array}{l}\text { Gregorová, M. } \\
\text { (2016) [35] }\end{array}$ \\
\hline 26 & $\begin{array}{l}\text { Atlas of the } \\
\text { European } \\
\text { novel:1800-1900 }\end{array}$ & $\begin{array}{l}\text { The author says he was piqued by the question } \\
\text { of why we don't have literary atlases. The } \\
\text { historical novels of the period under scrutiny } \\
\text { show significant relations between the plot, } \\
\text { characters and geography. The book is } \\
\text { illustrated with a fascinating array of } 100 \text { maps } \\
\text { to plot the connections between place, politics, } \\
\text { social hierarchy and economy in the novels }\end{array}$ & $\begin{array}{l}\text { Moretti, F. } \\
\text { (1999) [36] }\end{array}$ \\
\hline 27 & $\begin{array}{l}\text { Introduction: The } \\
\text { reassertion of space } \\
\text { in literary studies }\end{array}$ & $\begin{array}{l}\text { The author has argued that creative writers } \\
\text { engage in a form of literary cartography by } \\
\text { which they figuratively map the real and } \\
\text { imagined spaces of their worlds, sometimes of } \\
\text { those in the text and many a time of those } \\
\text { spaces beyond the scope of the works. }\end{array}$ & $\begin{array}{l}\text { Tally, R. T. } \\
(2017)[38]\end{array}$ \\
\hline 28 & Transgressivity & $\begin{array}{l}\text { The author examines in detail the history and } \\
\text { progression of cartography not only in novels } \\
\text { but also in movies. Maps and mapmakers are } \\
\text { brought to the forefront. A map sometimes } \\
\text { takes on the nature of a palimpsest, which has a } \\
\text { substantial element of overwriting. The old is } \\
\text { retained and overwritten by the new name or } \\
\text { reference. }\end{array}$ & $\begin{array}{l}\text { Westphal, B. } \\
\text { (2007) [39] }\end{array}$ \\
\hline 29 & $\begin{array}{l}\text { Place names and } \\
\text { identities }\end{array}$ & $\begin{array}{l}\text { The primary focus of this article is the } \\
\text { intertwining relationship between place names } \\
\text { and identities of the places. Place names can be } \\
\text { connected to the topography of the place or can } \\
\text { be links to its history and thus have a major role } \\
\text { in building the identity of the place. The article } \\
\text { points out the relationship between place, place } \\
\text { name, and the feelings associated through } \\
\text { experiences in the place, thus contributing } \\
\text { towards identity. }\end{array}$ & $\begin{array}{l}\text { Helleland, B. } \\
\text { (2012) [40] }\end{array}$ \\
\hline 30 & $\begin{array}{l}\text { The imaginary } \\
\text { landscapes of Jim } \\
\text { Crace's Continent }\end{array}$ & $\begin{array}{l}\text { The author uses the geocritical approach to } \\
\text { analyse the novel of Crace, who created } \\
\text { imaginary landscapes or settings for his works. }\end{array}$ & $\begin{array}{l}\text { Chalupský, P. } \\
\text { (2018) [41] }\end{array}$ \\
\hline
\end{tabular}




\begin{tabular}{|c|c|c|c|}
\hline & & $\begin{array}{l}\text { The seven stories have a thread that runs } \\
\text { through all of them - their geography - and the } \\
\text { settings are locales in an imaginary continent. }\end{array}$ & \\
\hline 31 & $\begin{array}{l}\text { Recovering } \\
\text { inspiration in the } \\
\text { spaces of creative } \\
\text { writing }\end{array}$ & $\begin{array}{l}\text { This paper rues the fact that the connections } \\
\text { between geography and literature have not } \\
\text { received the attention that they deserve and } \\
\text { explores the process of writing by looking up } \\
\text { works from geography as well as literature. }\end{array}$ & $\begin{array}{l}\text { Brace, C., et al. } \\
\text { (2010) [42] }\end{array}$ \\
\hline 32 & $\begin{array}{l}\text { The people, place, } \\
\text { and space reader }\end{array}$ & $\begin{array}{l}\text { Henri Lefebvre, in The production of Space, } \\
\text { looks at the ways in which space is represented } \\
\text { and divides it into three compartments - } \\
\text { physical, mental and social space. He opines } \\
\text { that space cannot be considered in isolation and } \\
\text { is a sum total of the energy and contents in a } \\
\text { certain time frame. }\end{array}$ & $\begin{array}{l}\text { Gieseking, J. J., } \\
\text { et al. (Eds) } \\
(2014) \text { [43] }\end{array}$ \\
\hline 33 & Referentiality & $\begin{array}{l}\text { The philosophy of Lefebvre and geographers } \\
\text { like Soja is analysed to understand the } \\
\text { relationship between the phenomena of the real } \\
\text { world and fiction, between the physical space } \\
\text { and the ways in which it is presented in writing. } \\
\text { It is words that create pictures of space in the } \\
\text { mind. }\end{array}$ & $\begin{array}{l}\text { Westphal, B. } \\
\text { (2007) [44] }\end{array}$ \\
\hline 34 & $\begin{array}{l}\text { Place and human } \\
\text { being }\end{array}$ & $\begin{array}{l}\text { The connections between humans and place is } \\
\text { deeper than we envisage, says this philosopher, } \\
\text { even in this age of globalised travel and } \\
\text { interconnectivity. }\end{array}$ & $\begin{array}{l}\text { Malpas, J. } \\
\text { (2009) [45] }\end{array}$ \\
\hline 35 & $\begin{array}{l}\text { Exploring history } \\
\text { and culture: A } \\
\text { study of William } \\
\text { Dalrymple's City of } \\
\text { Djinns }\end{array}$ & $\begin{array}{l}\text { The author takes up the ways in which } \\
\text { Dalrymple, the celebrated writer of Indian } \\
\text { history, brings Delhi alive in his writing. To } \\
\text { him a city is not merely space and geography } \\
\text { but a living entity that a writer can breathe life } \\
\text { into by melding its history and present through } \\
\text { characters and their stories. We understand how } \\
\text { the methodology of presenting a city affects the } \\
\text { reader's experience of reading. }\end{array}$ & $\begin{array}{l}\text { Rathee, H. } \\
\text { (2018) [46] }\end{array}$ \\
\hline 36 & $\begin{array}{l}\text { Decoding a city: } \\
\text { Common thread } \\
\text { that connects Delhi } \\
6 \text {, City Of Djinns } \\
\text { and Covid-19 }\end{array}$ & $\begin{array}{l}\text { The author attempts to understand a city } \\
\text { through a movie, a travelogue and a pandemic. } \\
\text { The history of the city and the cultural signposts } \\
\text { give the people residing there a thread of } \\
\text { continuity that connects them, their lifestyle } \\
\text { and their lived experiences even in a pandemic. }\end{array}$ & $\begin{array}{l}\text { Dogra, N. } \\
(2020) \text { [47] }\end{array}$ \\
\hline 37 & $\begin{array}{l}\text { Moving through } \\
\text { modernity: Space } \\
\text { and geography in } \\
\text { modernism. }\end{array}$ & $\begin{array}{l}\text { The publication offers a sweeping account of } \\
\text { modernism from the viewpoint of literary } \\
\text { geography. In stimulating new readings of } \\
\text { several texts, it demonstrates how space and } \\
\text { geography were also central concerns for } \\
\text { modernists, and proceeds to critique the } \\
\text { differences between space and place. }\end{array}$ & $\begin{array}{l}\text { Thacker, A. } \\
\text { (2003) [48] }\end{array}$ \\
\hline 38 & $\begin{array}{lr}\text { Place } & \text { and } \\
\text { experience: } & \text { A } \\
\text { philosophical } & \\
\text { topography } & \end{array}$ & $\begin{array}{l}\text { Malpas is well known in the discipline of } \\
\text { spatiality for his assertion that human living has } \\
\text { to be considered only in relation to a place. The } \\
\text { land around human habitation is a reflection of } \\
\text { the vision, abilities, hopes and dreams of the } \\
\text { people in it. }\end{array}$ & $\begin{array}{l}\text { Malpas, J. } \\
\text { (2018) [49] }\end{array}$ \\
\hline
\end{tabular}




\begin{tabular}{|c|c|c|c|}
\hline 39 & $\begin{array}{l}\text { Cities, sexualities } \\
\text { and modernities: A } \\
\text { reading of Indian } \\
\text { cinema }\end{array}$ & $\begin{array}{l}\text { This is an article that considers the unchanging } \\
\text { image of the city as the great Indian dream in } \\
\text { Indian cinema. It explores the rapidly } \\
\text { expanding engagement with cities in the form } \\
\text { of citycentric movies. Issues like the sexual } \\
\text { liberation offered by the anonymity afforded by } \\
\text { cities are tackled with sensitivity. }\end{array}$ & $\begin{array}{l}\text { Bose, B. (2011) } \\
{[50]}\end{array}$ \\
\hline 40 & $\begin{array}{l}\text { Elements of } \\
\text { Geocriticism. }\end{array}$ & $\begin{array}{l}\text { The author offers a composite idea of the } \\
\text { elements that go into geocritical theory of } \\
\text { literature. He posits multifocalization as the } \\
\text { most significant characteristic of the theory } \\
\text { with the importance shifting to the referent } \\
\text { from the writer, here the referent being space. } \\
\text { The perspectives of space through cinema, } \\
\text { plays, TV and travel guides may also be } \\
\text { considered. The association between the city } \\
\text { and novel is explored with reference to well- } \\
\text { known works of fiction, both historical and } \\
\text { contemporary }\end{array}$ & $\begin{array}{l}\text { Westphal, B. } \\
\text { (2007) [51] }\end{array}$ \\
\hline 41 & Of other spaces & $\begin{array}{l}\text { The author presents the idea of heterotopias to } \\
\text { get a better understanding of space as a } \\
\text { collection of people and things in a specific } \\
\text { environment. Starting with utopias, he moves } \\
\text { on to offer explanations of heterotopias, which } \\
\text { are places within places. }\end{array}$ & $\begin{array}{l}\text { Foucault, M. et } \\
\text { al. (1986) [52] }\end{array}$ \\
\hline 42 & $\begin{array}{l}\text { Toponyms as a } \\
\text { gateway to society }\end{array}$ & $\begin{array}{l}\text { This is a research study on the connection } \\
\text { between Abui, a Papuan language of Alor } \\
\text { Island of Indonesia and the toponyms of the } \\
\text { region. The findings show that the toponyms } \\
\text { reflect the rural lifestyles as well as the } \\
\text { connectedness with their lived spaces and } \\
\text { kinship of the people who speak the language. }\end{array}$ & $\begin{array}{l}\text { Gin, S. L. T. et } \\
\text { al. (2021) [53] }\end{array}$ \\
\hline 43 & $\begin{array}{l}\text { Theorizing maps } \\
\text { with literature }\end{array}$ & $\begin{array}{l}\text { The writer's objective is to add to the discussion } \\
\text { on map making, wherein it is pointed out that } \\
\text { literature is one of the fields that should be } \\
\text { harnessed so as to engage in the creative nature } \\
\text { of cartography. The end result is an } \\
\text { engagement with literature as a source of ideas, } \\
\text { concepts and possibilities for a geographer. }\end{array}$ & $\begin{array}{l}\text { Rossetto, T. } \\
(2014)[54]\end{array}$ \\
\hline 44 & $\begin{array}{l}\text { Melville, mapping } \\
\text { and globalization: } \\
\text { Literary } \\
\text { cartography in the } \\
\text { American baroque } \\
\text { writer }\end{array}$ & $\begin{array}{l}\text { Robert Tally argues that in his literary creation, } \\
\text { Melville, as if prescient of the world order to } \\
\text { come, did not reflect the parochial nationalism } \\
\text { of his time but rather charted a literary } \\
\text { cartography of a globalized world and } \\
\text { artistically tackled spaces beyond the narrow } \\
\text { confines of man-made boundaries of political } \\
\text { hegemony. }\end{array}$ & $\begin{array}{l}\text { Tally Jr, R. T. } \\
\text { (2009) [55] }\end{array}$ \\
\hline 45 & $\begin{array}{l}\text { The meaning of } \\
\text { place in old age }\end{array}$ & $\begin{array}{l}\text { The author seeks to provide an overview of the } \\
\text { changing role of spatial reflection in old age. } \\
\text { The significance that a particular space has in } \\
\text { infancy, teenage mid-adulthood and old age is } \\
\text { analysed. }\end{array}$ & $\begin{array}{l}\text { Howell, S. C. } \\
\text { (1983) [56] }\end{array}$ \\
\hline 46 & $\begin{array}{l}\text { World views: } \\
\text { Metageographies of } \\
\text { modernist fiction }\end{array}$ & $\begin{array}{l}\text { The book is a reflection on how twentieth- } \\
\text { century postcolonial writers deal with the } \\
\text { changing concepts of geography, space and }\end{array}$ & $\begin{array}{l}\text { Hegglund, J. } \\
\text { (2012) [57] }\end{array}$ \\
\hline
\end{tabular}




\begin{tabular}{|c|c|c|c|}
\hline & & $\begin{array}{l}\text { physical borders in the fictional worlds of their } \\
\text { literary narratives. What happens when space } \\
\text { becomes territory and is loaded with meanings } \\
\text { of control and political ownership is analysed. }\end{array}$ & \\
\hline 47 & $\begin{array}{l}\text { City signs: Toward } \\
\text { a definition of } \\
\text { urban literature }\end{array}$ & $\begin{array}{l}\text { Different meanings that writers of novels with } \\
\text { urban settings give to their cities is examined } \\
\text { with illustrations of passages from poems and } \\
\text { novels. The city has at times been demonized in } \\
\text { contrast to the countryside. Many citycentric } \\
\text { literary works have different perspectives of the } \\
\text { same city. }\end{array}$ & $\begin{array}{l}\text { Levy, D. W. } \\
\text { (1978) [58] }\end{array}$ \\
\hline 48 & $\begin{array}{l}\text { The protagonist and } \\
\text { the city: Istanbul in } \\
\text { Orhan Pamuk's A } \\
\text { strangeness in my } \\
\text { mind and The } \\
\text { museum of } \\
\text { innocence }\end{array}$ & $\begin{array}{l}\text { The paper looks at the ways in which Pamuk } \\
\text { deploys the plot twists and personas of his } \\
\text { protagonists to portray the history of Istanbul, } \\
\text { while considering two of his novels. Pamuk } \\
\text { converts the Istanbul of his novels from being } \\
\text { mere settings to conspicuous elements that } \\
\text { influence characterization and plot. }\end{array}$ & $\begin{array}{l}\text { Hezam, A. M. } \\
\text { M. (2020) [59] }\end{array}$ \\
\hline 49 & $\begin{array}{l}\text { City, identity and } \\
\text { dystopia: Writing } \\
\text { Lagos in } \\
\text { contemporary } \\
\text { Nigerian novels }\end{array}$ & $\begin{array}{l}\text { The author takes up four novels from Nigeria to } \\
\text { narrate how the city of Lagos is not only a } \\
\text { setting but an invaluable cityscape that shapes } \\
\text { the identities of the characters and offers a } \\
\text { dystopian view of the novels' plotlines. The } \\
\text { space - as depicted through the scents, sounds, } \\
\text { squalor and frenzied scenes of busy streets in } \\
\text { Lagos - is almost the hero of the novels. }\end{array}$ & $\begin{array}{l}\text { Nnodim, R. } \\
(2008) \text { [60] }\end{array}$ \\
\hline 50 & $\begin{array}{l}\text { Introduction: The } \\
\text { reinsertion of space } \\
\text { in the humanities } \\
\text { and social sciences }\end{array}$ & $\begin{array}{l}\text { The author is happy to note that geographers } \\
\text { have moved to becoming exporters of analysis } \\
\text { and experiences from being mere importers } \\
\text { from humanities. Space is about history and } \\
\text { lived experience rather than only an empirical } \\
\text { narration of information. }\end{array}$ & $\begin{array}{l}\text { Warf, B. et al. } \\
(2008)[61]\end{array}$ \\
\hline 51 & $\begin{array}{l}\text { The cultural } \\
\text { geography of early } \\
\text { modern drama, } \\
1620-1650\end{array}$ & $\begin{array}{l}\text { The author makes a point about cultural } \\
\text { geography to explicate how it is a means to } \\
\text { understand how we make sense of place. She } \\
\text { quotes Mike Crang to state how geography is a } \\
\text { tool to understand cultural nuances and the } \\
\text { ways in which drama used spaces to denote the } \\
\text { cultural milieus. Places hold meanings for } \\
\text { people based on the activities played out in } \\
\text { those places and plays explored this facet. }\end{array}$ & $\begin{array}{l}\text { Sanders, J. } \\
\text { (2011) [63] }\end{array}$ \\
\hline 52 & $\begin{array}{l}\text { Literature \& the } \\
\text { American urban } \\
\text { experience: Essays } \\
\text { on the city and } \\
\text { literature }\end{array}$ & $\begin{array}{l}\text { This is a volume of poems and essays that looks } \\
\text { at the relations between literature and the city. } \\
\text { Cities have motivated writers and poets create } \\
\text { such strong imagery that readers are induced to } \\
\text { revisit them to rediscover the sensations evoked } \\
\text { in the process of reading the creations in which } \\
\text { they were settings. }\end{array}$ & $\begin{array}{l}\text { Jaye, M. C., \& } \\
\text { Watts, A. C. } \\
\text { (Eds) }(1981) \\
{[67]}\end{array}$ \\
\hline 53 & $\begin{array}{l}\text { The city as catalyst: } \\
\text { A study of ten } \\
\text { novels }\end{array}$ & $\begin{array}{l}\text { The author analyses novels, plays and poems to } \\
\text { see the impact that cities have on literature. She } \\
\text { mentions the ambivalent attitude of writers } \\
\text { towards cities who many a time extoll the old } \\
\text { cities as places of learning but demonise the } \\
\text { modern ones as dens of vice. }\end{array}$ & $\begin{array}{l}\text { Festa- } \\
\text { McCormick, D, } \\
\text { (1979) [69] }\end{array}$ \\
\hline
\end{tabular}




\begin{tabular}{|c|c|c|c|}
\hline 54 & $\begin{array}{l}\text { The Post-9/11 city } \\
\text { in novels: Literary } \\
\text { Remappings of } \\
\text { New York and } \\
\text { London }\end{array}$ & $\begin{array}{l}\text { This is a study of how New York and London } \\
\text { are represented in novels written after } 9 / 11 \text {, that } \\
\text { have the incidents of the day as plots and } \\
\text { examine the genre of city novels that have the } \\
\text { city as a character, where real and fictional } \\
\text { settings merge to form a simulacrum. }\end{array}$ & $\begin{array}{l}\text { Golimowska, K. } \\
\text { (2016) [70] }\end{array}$ \\
\hline 55 & $\begin{array}{l}\text { "Song of the City" } \\
\text { and "Mine Boy": } \\
\text { The 'Marxist' } \\
\text { novels of Peter } \\
\text { Abrahams. }\end{array}$ & $\begin{array}{l}\text { The author examines the impacts of the urban } \\
\text { milieu on the protagonists of two novels by } \\
\text { Peter Abrahams, the South African novelist. In } \\
\text { Song of the city, the hero longs to return to the } \\
\text { city in search of enlightenment almost as if } \\
\text { wishing to break free from the shackles } \\
\text { imposed by his tribal past. Mine Boy, on the } \\
\text { other hand is an exploration of colonisation and } \\
\text { its impacts on Xuma, the protagonist, who } \\
\text { suffers alienation in the degenerate world of the } \\
\text { township in the big city. Clearly the city is a } \\
\text { major character in both the novels. }\end{array}$ & $\begin{array}{l}\text { Wade, J. P. } \\
\text { (1990) [73] }\end{array}$ \\
\hline 56 & $\begin{array}{l}\text { New York city in } \\
\text { Don } \\
\text { novels }\end{array}$ & $\begin{array}{l}\text { New York is much more than a mere setting for } \\
\text { the novels of Don DeLillo. It is a key } \\
\text { component in the formation of an Italian } \\
\text { American identity for the immigrants. The } \\
\text { author points out that the author and the city are } \\
\text { entwined in such a way as to be interdependent. } \\
\text { Names of real places such as hotels, streets, } \\
\text { cafes and museums enhance the foregrounding } \\
\text { of the city as a major player in the plot } \\
\text { development and progression of characters. }\end{array}$ & $\begin{array}{l}\text { Gravano, A. J. } \\
\text { (2011) [76] }\end{array}$ \\
\hline 57 & $\begin{array}{l}\text { A sense of place } \\
\text { within } \\
\text { landscape the } \\
\text { cultural settings. }\end{array}$ & $\begin{array}{l}\text { The authors present a study on the impacts of } \\
\text { landscape elements on culture. The perceptions } \\
\text { and responses of human beings to their physical } \\
\text { settings can change, depending on their culture, } \\
\text { habits and belief systems. When city planners } \\
\text { do not recognize the significance of cultural } \\
\text { aspects while planning developments in the city } \\
\text { it results in disoriented buildings. A } \\
\text { combination of physical, spiritual and social } \\
\text { attributes creates the sense of place. }\end{array}$ & $\begin{array}{l}\text { Mohammad, N. } \\
\text { et al. (2013) } \\
\text { [92] }\end{array}$ \\
\hline 58 & $\begin{array}{l}\text { Bombay Novels: } \\
\text { Some Insights in } \\
\text { Spatial Criticism }\end{array}$ & $\begin{array}{l}\text { The city is an act of human creation. It is } \\
\text { fashioned as per the political, economic and } \\
\text { cultural aspirations of its builders and planners. } \\
\text { While some cities were built to guard its people } \\
\text { from onslaughts of enemies as also natural } \\
\text { calamities, some were fashioned around trade } \\
\text { and a few around religion. The city also } \\
\text { provided opportunities for inflammation of } \\
\text { passions through cultural diversity. It is no } \\
\text { wonder that the city is the centre of literary } \\
\text { endeavours. }\end{array}$ & $\begin{array}{l}\text { Mantri, M. } \\
\text { (2019) [100] }\end{array}$ \\
\hline
\end{tabular}

\section{Correlated works:}

4.1 Buttimer gets lyrical as she reminds us of a song by John Denver to point out that sentimental references to place ring through much of modern poetry and song. Nostalgia is a well-recognised sentiment with regard to human feelings associated with events and places. Nostalgia is a longing for a period or place in the past, almost always associated with joy. Such recollections of one's past are 
naturally those that stayed as impressions about events, people and places and got imprinted on the psyche. Memories associated with places support us to form identities and can improve self-esteem. Nostalgia brings up pictures and recollections that might be of some real or imagined situations and make rural life seem like an idyll for someone who has moved to an urban milieu. It may well colour the perspective of the novelist when she writes about the hometown that was racked by poverty and dirt but now seems desirable since it is tinged with nostalgia. Time has erased the harsh edges of suffering and lent the childhood village a nostalgic glow [3].

4.2 Mullin explicates how an engagement with the life and concepts around the city developed from the mid-19th century to the modernist period. She writes that a city provides ample scope for modernist literature. It has enough plotlines, happenings, experiences and novelty to offer a medley of emotions to the writer. She brings up the concept of the flaneur, who takes pleasure in sauntering casually through the streets to observe people and their behaviours. The city affords one anonymity and this is a luxury that is not available in the sparsely populated countryside. Works of authors ranging from Baudelaire to Edgar Allan Poe, RL Stevenson, Joseph Conrad and Virginia Woolf to TS Eliot are examined to see the ways in which cities appear in them. Desolation appears to be a key component in city living. She concludes that city life is extolled and reviled in equal measure [4].

4.3 Sengupta speaks of a soul that a city seems to harbour within it. This may change with time and the happenings down the years, yet writers seek it so as to offer the readers an idea of the type of lives led by the characters in the writings. All ancient cities abound in myths and have histories replete with interesting individuals, that stick on and colour the lives of even fictional characters. Delhi is doubtlessly one such city and the author examines various works of fiction, travelogues, biographies, plays and television series, even civic movements to speak of the different versions of Delhi and its underbelly. She concludes that a city, ultimately is not identified with its monuments, or civic spaces or even seats of power; rather its spirit lies in the way the people who live there, rich or poor, powerful or powerless, consider the city in their hearts and minds [5].

4.4 In an interview with the celebrated Toni Morrison, the interviewer Step to is, first of all, interested in the strong sense of place that permeates her novels. Morrison reflects on the fact that a woman, perhaps has a stronger sense of place than a male because she is constantly moving things in a room and has an attachment to the concept of place. Morrison speaks about a place being more than the political entity, physical features and man-made artefacts. The idea of the place lies in the details, the emotions and mental states of the people who are residents of the place. While writing Sula, she purposely set out to make the neighbourhood a predominant character, she says, though the town of Medallion was entirely fictional, based on her mother's narrative of her childhood [19].

4.5 Day offers a narration of ten city novels that range from the late nineteenth century to the early twenty-first. Open City is by Teju Cole and is set in the Big Apple, New York, with the protagonist, a Nigerian immigrant, observing life in Manhattan. Sister Carrie by Theodore Dreiser has Chicago as the backdrop, with modernity giving way to changing values on morality. Ulysses by James Joyce is a novel that takes a reader on a stroll of Dublin's landmarks. In Bonfire of the Vanities, the author Tom Wolfe takes the reader through graphic descriptions of New York's skyscrapers wherein reside Wall Street tycoons and politicians of different hues. Charles Dickens has written about London in many novels but Bleak House is famous for its descriptive opening paragraph about the bleakness of the city weather in November. The city of Moscow is the backdrop with events that reflect the author Mikhail Bulgakov's political side in The Master and Margarita. In NW, the novelist Zadie Smith roots her characters in London and the title itself is part of the postal code of an area in the city. The Dog has as its protagonist a lawyer who shifts to Dubai from Manhattan. At first he detests Dubai, which is made out to be a hollow space of decadence and high-rises, but later he finds that he detests Manhattan equally. Rohinton Mistry gives us a realistic portrayal of Bombay during the Emergency days in A Fine Balance and John Lanchester gives us a peek into the London of the first decade of the twenty-first century in Capital [20]. 
4.6 Walonen writes that while reading about place is integral to developing and experiencing a sense of place, writing about place is a cathartic experience that brings the experience to life and makes it tangible and brings up word pictures in the mind's eye. Students who live away from their hometowns can get to know the places where they have settled in for higher education, through literature - from their own cultures and through an acceptance and understanding of the writings of the host place. Students should be asked to reflect on their preconceived notions of the new place and its culture to loosen the grip of cultural stereotypes. Asking them to read the writings of local writers would also help them get to know the new place better. Students who migrate to foreign lands for studies are able to acquire a nuanced sense of place through planned efforts [21].

4.7 Rosenthal puts forward a strong case for foregrounding cities in novels. According to her the city has to be more than a mere setting or backdrop for the plot in urban fiction. The city must guide the mode of representation wherever feasible. Secondly, urban space must be a significant player in creating the character as well as the plot; the urban condition must lead the way for discussion of the text. She quotes Rob Shields who referred to the city in picturesque terms as a slippery notion. Defining terms such as urban and city are becoming more and more difficult because of the differences in urban lifestyles. The fluid interpretations of space have made cities become representations of people's dreams, aspirations and failures as well [22].

4.8 Peraldo is convinced that time and space are intrinsically linked in fiction. They form an important aspect of the setting. When and where the action or event takes place is one of the first questions the reader brings up while reading the text. Mikhail Bakhtin gave us that interesting word to the quintessential time-space combination - chronotope. Considering the new spatial turn in literary scrutiny, time seems to have ceded place to space as a significant aspect of analysis. Space has deeper implications as a theme and a new tool of analysis. Literature is specifically suited to the description of spaces, as is evident from Muriel Rosemberg's opinion that literature is the artistic form of geography [23].

4.9 A journal of the plague year by Defoe is a literary creation that can be considered as a historical novel, a blend of fact and fiction, though it is titled as a journal. The narrator gives us a realistic picture, with lists of casualties as well as other facts and figures, about the happenings in seventeenth-century London, wracked by plague. The narrator gives us titbits of conversations picked up from pubs and the streets in London, takes us through the specific alleys and sectors where the horrors of the disease, compounded by the apathy and abject lack of accountability of the ruling class took its toll on the citizenry. We are given rich details such as names of streets, addresses, descriptions of churches and hospitals, riversides, quays and London's nooks and corners. It is this realism that makes it an authentic account of the outbreak of plague and its aftermath in London though the author was only five years old when the epidemic held the city in its vices. The reader can easily picturise the happenings through the descriptions and specific details employed by the narrative [24]. Cities, due to the density of population are more prone to epidemics than the countryside which enjoys more open spaces. The recent upsurge of the Covid 19 pandemic is evidence of this trend. Narratives of cities cannot escape the impacts of such pandemics [96].

4.10 Malkki asks us to look at the changing definitions of rootedness and attachment to a place in relation to displacement. While it cannot be denied that humans are a species that form intimate, almost metaphysical relations to the places they inhabit, so much so that their identities are shaped around them, these aspects have to be seen in a new light in a world that is constantly shifting in terms of diasporas and the displaced. While the homeland might never be accessible to many, they may recreate them through memories. Those who live off the land, especially, have a worshipful attitude to it and feel a loss of rootedness. The author gives us a comparative study of rootedness between two sets of Hutu refugees - those who had lived together in a camp and those who had lived in a township. Their sense of attachment and ability to newly chart their identities differed [37]. Place attachment is a phenomenon the occurrence of which is seen to increase with age whereas higher education and economic levels can impact such attachment negatively [99]. 
4.11 Australia, the island continent, was seen as some sort of tabula rasa by the colonialists when they first stepped onto it. Indeed, Australians are deeply rooted to their soil and form a cultural identity that enables their literary fiction and movies to be defined by this sense of space and territory. Stadler, Mitchell and Carleton give us a geocritical analysis of different genres of fictive texts as well as plays and movies. Their plays have themes that are connected and coloured by the concepts of colonialism, nationality, land and more importantly aboriginal contestations of land. The reader is provided with an interesting take on cultural topography and spatiality in a land that has space and landscape as a theme in literary works and analysis [62].

4.12 Soja offers an autobiographical rumination on his journey from being a geographer to a political geographer. He takes a retrospective view on his learning and conclusions on the impact of space on sociology, anthropology and literature. There is a relook at his own learning of spatiality and he takes comfort from the new interest in the concept that has sprung up in the social sciences. Pointing out the hitherto lower position attributed to space as against time, he is quick to reassure sceptics that he is not pitting space against history but merely seeking to bring about a balance between spatial/geographical considerations and the traditional hegemony of the temporal/historical aspects. In any struggle to solve the problems of humanity we cannot deny that humans are temporal as well as spatial beings. He takes recourse to the views of Lefebvre and Foucault to emphasise this view [64].

4.13 Borden analyses the contributions of Georg Simmel to the multidisciplinary aspects of space and spatiality, especially with regard to big cities. Simmel was of the view that space is a socially constructed idea that went beyond the mere physical. It was not fixed but a continually changing entity and a significant player in the consciousness of a metropolis. Simmel made a difference between objective culture considered as an externalisation of life brought about by aspects such as capitalism and technology and subjective culture of the individual which might resist this external stimulus. Simmel is seen as something of a flaneur of modernity and its representations, especially the architecture [65].

4.14 Advances in technology have had an impact on the relationships between maps and our ability to describe and narrate. Places that are mentioned in literary works, be they novels or historical documents, can now be located and a mapping done through geocoordinates. In the humanities, the spatial turn has resulted in a special engagement with maps and the science of cartography. A map is a storytelling tool but it can also put a dampener on the curiosity of the reader by making things look mundane and drab. Google Maps is a tool of technology that has become ubiquitous and future generations may not be able to envisage a time when they did not exist. This technology makes Google Maps inevitable for spatial narratives. Caquard quotes a character in a French novel who has this to say about the map - that it seems to be more interesting than the actual space. Perhaps the map is a hyper-real version of humdrum reality and that is what Google Maps are portraying [66].

4.15 Western poetry took recourse to rural idylls for thousands of years. Pastoral settings dominated the discourse on poetry so much so that it may perhaps, never have resonated with a predominantly urban populace. While the city poet could never go to the village to live with the shepherd he waxed eloquent in his poems, neither could the shepherd read it in his rural commune. Howe calls it a game of the imagination. There is an element of artifice in such romantic pastoral poetry that satisfies some deep felt need of the psyche. Cities were seen to be pits of sin such as Sodom and Gomorrah. The city is a den of temptation and threatening at the same time. The city is always suspect in the eyes of traditionalists, writes Howe [68]. Auden considered urbanised industrial society to be ugly and banal $[93,94]$.

4.16 Wirth-Nesher throws up an interesting question of whose city it is, while writing the urban novel. Is it that of the financially challenged senior citizen, the lonely immigrant or the rich socialite? All urban novels cannot be described as being modern. The earlier urban novels had alienation and isolation as tropes whereas the modern urban novel might have the protagonist seeing the city as a release from constricting orthodoxies of the home. Home itself is a quixotic notion. The public and private spaces also are not strictly divided in the modern urban novel and the home seems an amalgam of both. The 
street is a deciding factor in denoting privacy and belongingness [72]. City based novels might also have characters with body image issues brought up through social media and the comparisons that such images evoke. The characters who inhabit city literature would be affected by these notions [98].

4.17 Kumar observes that the Hindi novelist Premchand's works are considered social critiques and are mostly seen as commentaries on the rural India of the time and hence the fact that he wrote prolifically on themes connected to city living has bypassed critics, mostly. While his earlier novels did show villages as being ideal places for living, he did not hesitate to shed light on the casteist, bigoted and superstitious aspects of rural life that lead to the exploitation of the poor, socially disadvantaged and women. The city, according to Premchand, was responsible for the people's mass exodus towards industrialization that did not help them achieve peace and security and pushed them into the clutches of the oppressor, the British. The author does not justify Premchand's opinions of the city but does not doubt his sincerity. Premchand's novel Sevasadan is a realistic portrayal of a courtesan who is the focus of a discussion, in the Municipality of the city of Benares, as to whether the courtesan's quarters need to be moved beyond the city. Many novels have characters that flit between the village and city. Perhaps it is this shifting setting that allowed the novelist to bring up the moral decadence that afflicted the city of his times [75].

4.18 Claire Etcherelli's novels may be described as realistic Parisian novels. The city of Paris has many parts to play. It not only is a character but can also be said to have character. The city's thoroughfares and street plans function as metaphors to describe the mazes that the reader must traverse as the reading progresses. Descriptions of the real city are entangled almost, in descriptions of the imagined city, at times almost as if it is a palimpsest. Sara Poole tells us that the image of the city formed in the minds of the reader may have, at best, a tenuous relationship with the city as it exists. That is why Paris is both the context and the code that reveals the character's angst and triumphs. [78]

4.19 Memory, history and identity are interlinked; any writer ignores this at her or his own peril. Barcelona, a city that is the capital of the Catalonia province and a major cultural and tourist hub is the city that is examined in its representations in 5 novels by contemporaneous Spanish writers Marse and Mendoza. Both are from the same province and write about the city not only as a setting but also as a factor that offers a sense of identity to the inhabitants. The themes that are highlighted in the novels are pertinent to the identity of not only the Catalans but also to all Spanish people. A city is its art, cultural beliefs and especially its history. Memory contributes to a collective heritage though it can be tricky ground to negotiate [79]. Writings of the city can no more ignore its history than a fish can live out of water, as is observed from the novels of many Scottish writers who base their stories in Glasgow and express themselves with a strong Scottish identity, a Scottish voice that gives agency to the silent yearnings of the people of the land [80]. Austerlitz, by WG Sebald is an attempt to reconstitute identity through a memory of events by returning to the place of occurrence. The novel feels almost like travelogue, in its authenticity of details about the cities that are the setting [83]. Isabel Roth quotes Svetlana Boym who has referred to the city as being a crossroads of sorts that weaves nostalgia and modernity, which gives scope for the expression of repressed memories. Cities are thus repositories of memories and have a deep psychological significance [84]. Marlowe's cities also embodied this sentiment [89]. Histories of colonialism can create heterotopias where migrants are othered and denied entry into the hallowed gates of the resident settlers. Space thus becomes a battleground and the city once again creates alienation as is evident in Harvest of Thorns by Zimbabwean novelist Chinodya [85].

4.20 There are works of popular fiction that have transported readers to fictitious places that they never forgot. These cities and lands captivated the readers to such an extent that the popularity of the books seemed to be due to the places that were used as settings, imaginary and fanciful. The writers created such fantastic lands that readers kept revisiting them in their imaginations, tourism industries were set up around them and they became imprinted in the psyches of the reading public through rereading, time and again, to savour the pleasures of the strange cities and their characters. Hogwarts of the Harry Potter series, Coleridge's Xanadu, RK Narayan's Malgudi and Raja Rao's Kanthapura are a few such imaginary lands that became iconic [87]. 
4.21 The city can emancipate a woman in ways that a rural setting may not; it is a space that enables her to confront her needs and express them as a woman. The city allows for the expression of female identity to be formed, developed and rediscovered, with its complex systems and layers of functioning. The population density also ensures that female friendships can flower in the liberating air of the city, away from the constrictions of oppressive rural hierarchies, as is evident in the story of Enitan, the female protagonist who moves to Lagos in Everything good will come by the female Nigerian writer Sefi Atta [86]. In India, technology and urban lifestyles have seen divorce rates in cities go up from $7.4 \%$ to $11 \%$. While this might seem an alarming prospect it perhaps points out to a social upheaval that happens with migration to cities. These aspects will surely affect the portrayal of the characters in urban fiction [97].

4.22 Chetan Bhagat's novels do not have rural settings. Most of them have the smaller Indian cities as a background and One Night @ The Call Centre is set in Gurgaon, the city of glitzy restaurants, pubs and malls and typifies the new India that is very much a part of the ambitions and aspirations of the upwardly mobile, middle class Indian youth. The setting is a Call Centre and the characters could exist in any city, not just India. Their value systems are not based on the traditional Indian family set up, mostly, except for Radhika, that too in the initial parts. The plotline and characters are completely in contrast to the themes of the big three of Indian writing in English - MR Anand, R Rao and RK Narayan - whose writing responded to the needs of the era just after gaining independence. Bhagat's characters have dreams of financial growth backed by an India that is stepping into the internet age and youngsters with the ability to speak English, though they may be from smaller towns. They are not hampered by the patriarchy, orthodoxy and superstitions that still afflict rural India, though this is not to say that these new values are without their own conflicts, according to Rodrigues [81].

4.23 Bombay, now Mumbai, is a cultural cosmos that in its own way, typifies India, writes Shahani. Just as we cannot have a single representative of Indian culture, for obvious reasons of multiple languages, cuisines, geographies, weather, races and religions, so too the city of Bombay does not have a single identity. There are polyphonous voices - many voices harmoniously blending together to form a symphony. The novels that have been written on Bombay, be they by Salman Rushdie, Rohinton Mistry, Shashi Deshpande or Anita Desai each have their own voice, theme and space. These writers have mapped Bombay, sometimes geographically and sometimes as figments of their imagination. Many a time the details are so realistic as to give the reader a dreamy sense of being teleported to the space. Bombay is a microcosm of India and the novels on Bombay have permitted other writers with different locales as settings to follow the style of cartography employed by these novelists [82].

4.24 Chambers examines the city of Lahore, the social and cultural capital of Pakistan, which is analysed through the lens of Soja's concept of space having three dimensions: as given by nature, as constructed by society and existing in the mind space. It considers the portrayal of the city of Lahore in the novels of Mohsin Hamid and Bapsi Sidhwa, well-known writers from Lahore, a city that is of political and economic significance to the province of Punjab. A border city that bore the brunt of partition, Lahore is at once a city with a confluence of different topographies, economic strata, languages and religions. The startling presence of Heera Mandi, the area peopled by courtesans and pimps, which is situated in an area that has a mosque, is interestingly depicted to seem like a carnival of sorts, an admixture of sex workers, and drug peddlers on one hand and landlords, politicians and religious heads on the other. Chambers concludes by describing Lahore as a palimpsest of histories, real and imagined [90].

4.25 Virginia Woolf's novels reveal, through a stream-of-consciousness style as much about the characters as about the cities they are located in as a setting. The details give us an idea of the state of technology of the times as well as aspects of the class system that was practised in Britain. She used to use the motor omnibuses that were introduced newly in London, as a step up from the horse-drawn carriages and used the descriptions of movements, shape, colours, routes taken by these omnibuses and ticket fares. Her first-hand knowledge about omnibus-related trivia such as the traffic congestion as well as accidents and doubtlessly the chaos caused by sudden strikes makes for interesting titbits that make the omnibus a symbol of the city in her novels [95]. 


\section{NEW RELATED ISSUES :}

The writer has many ways to convert a city, that was hitherto merely a backdrop, to that of a significant aspect of the work that exerts its own influence on the proceedings.

One of them is to take the posthumanist route, depicting humans and machines interfacing with and transforming each other in new, complex and provocative ways to make the city have a robotic lifestyle through a blending of automation and mechanization. This belongs to the genre of science fiction, mostly. We can find this in The Loop, a novel by Benjamin Oliver, published in 2020. It gives us a city that is so technologically progressive that the people depend, almost fully, on machinery and computerisation. One can also personify cities, giving human qualities, feelings, agency or characteristics to inanimate objects such as the City Square or City Town Hall or even malls and other prominent landmarks of the city, as is done in NK Jemisin's 2020 novel The City We Became. Here, the objects are personified and as is the case with all lifeforms - prone to decay and death [1].

An interesting aspect of portraying cities, is their depiction through fantasy with characteristics that make them seem quasi-realistic with futuristic elements added on. Cities may be floating metropolises such as in Marie Lu's Legend Trilogy [30]. An interesting division of narrative space has been offered by Marie-Laure Ryan in the article Space, by delineating them under headings such as spatial frames, settings, story space, narrative (or story) and narrative universe [71].

\section{IDEAL SOLUTION, CURRENT STATUS \& IMPROVEMENTS REQUIRED :}

Down the ages, works of fiction have been described as narratives of a series of events. Time was the aspect that was foregrounded. Time dictated the narration, turn of events and plots. Space was never given its due. Space was considered a static aspect that deserved to be relegated to the background. Be it pastoral settings or cityscapes, very few poets and novelists cared to give space its due. It is only after the Second World War that space began to be viewed as being equally if not more important than time in narrative practices [25]. With the cumulative impacts of postcolonialism, rise of globalized economies and advancement of information technology on a worldwide scale, with geographical boundaries blurring, philosophers and theorists such as Lefebvre, Soja and Westphal offered us various viewpoints through which literature underwent a spatial turn. While events narrate what happens to the human, the human herself or himself occupies space, which changes with the actions, perceptions and histories of the people who use it and nature which acts on it. Space has more meaning than mere geographical existence and currently we do see space as more than mere setting. Cities have been described in detail down the ages and their histories have resulted in wars, destitution, isolation as well as formation of new cities and cultures. Writers have presented space through texts, maps and now as geographical coordinates.

The ideal situation would be for more such foregrounding of cities in novels so that narration of space adds to the reader experience and a meaningful rounding of all that it means to be in a city, with its sights, smells, sounds, history, architecture, topography, literature, music, dance and food, the people and their beliefs, values and attitudes, be it real or fictional.

The improvement sought over the current situation would be to see details of the city being woven into the narration in works of fiction, especially novels, so that the world would become more aware of the cultural nuances of the myriad cities, metros, tier 2 cities and smaller mofussil towns of our own country. Stereotyping of the city as a hell, which was not uncommon in the last century at the start of industrialisation, as witnessed in TS Elliot's poetry, needs to be looked at anew [77].

\section{RESEARCH GAP :}

Most studies on the portrayal of cities in fiction have been about novels in the western world and hence on cities in countries other than India. A study by Wolfreys J. [88] is one example. Studies about the portrayal of Indian cities in fiction have not really been made on a significant scale. There is scope for investigation into the research gap by attempting to fill it by discussing and bringing to light the need to offer more exploration into details about cities which form the setting in Indian novels, be it in any language. India is referred to as a subcontinent - an amalgamation of various cultures. The sheer variety 
of cultural signposts such as language, architecture. history, topography, weather, cuisines, religions, beliefs, economic levels and spending patterns is mindboggling. Many of our metro cities are very unlike each other, uniquely different. The number of studies made on the presentation of the country's cities through its novels is meagre, especially noting such cultural heterogeneity. The research gap noticed here is a need to offer more studies on how our cities are portrayed in novels.

\section{RESEARCH AGENDA :}

The following are methods through which the research gap is sought to be filled by the researcher so as to offer solutions to the research questions:

1. Participation in research projects in the related field to get more focused information on the topic.

2. Submission of papers in conferences to give a fillip to the central idea of the portrayal of cities in fiction.

3. Publication of papers in scholarly journals through consultation with peers and seniors so as to offer traction to the idea of foregrounding of cities in novels.

4. Publication of the mega research project as a book with the objective of popularising the concept of the significance of portraying cities in fiction to get more novelists to employ the concept in greater detail

\section{ANALYSIS OF RESEARCH AGENDAS :}

Research agendas of literature depend on publication so as to get focused attention and critical reviews. With the proliferation of social media and internet-based services in the field of publication, it is incumbent upon a researcher to venture into publication in peer-reviewed journals so as to let readers worldwide get involved in the research questions and offer solutions that might have been missed. The research gap in the field of literature studies and critical literary theories is an ever-expanding one and scholarly research is of the utmost need to offer solutions in an age where perceptions are changing based on the ability of the online world to offer visuals and commentaries on the state of the research.

\section{FINAL RESEARCH PROPOSAL IN THE CHOSEN TOPIC :}

The proposed research will explore the various aspects of the portrayal of cities in fiction with a focus on selected works of Indian novelists. The novels chosen have different cities of India as the backdrop - Bengaluru, Kolkata and Chennai. This variety will offer opportunities to study the multifarious ways in which the culture of the country's cities contributes towards our identity as Indians. The novels chosen are published in the $21^{\text {st }}$ century and while two of them offer a ringside view of city life in the last two decades, the time of significant churning due to the IT revolution, interconnectedness and aspirational lifestyles, one of them is set in the late 1960s and is a graphic portrayal of the Naxalite movement in the then city of Calcutta.

\section{Works included in the study:}

1. Hasan, A. (2009). Neti Neti: Not This Not this. New Delhi: Roli Books

2. Mukherjee, N. (2014). The Lives of Others. Mumbai: Random House

3. Tirumurti, T.S. (2012). Chennaivaasi. Noida: Harper Collins

The proposed research will investigate the ways in which the novelists use the cities in which the plots are set to showcase the city as a significant presence. There will be a process of comparison and contrast to arrive at conclusions for purposes of doing this exploratory research in an objective and systematic manner. The proposed research is planned to be accomplished within three years.

The proposed study is embarked on with the following objectives:

The broad objective of the study is to undertake a secondary literature review and present summarized data on the portrayal of the city in the chosen novels. In addition, these are the other objectives:

1. To gain an understanding of the existing research around the presentation of space in fiction writing.

2. To comprehend the debates relevant to the foregrounding of cities in novels.

3. To learn about associated concepts, viewpoints, and techniques that are used to examine the significance of space in different forms of fiction.

4. To gain insights into how researchers apply the theory under study to critically analyse works of fiction. 
5. To learn more about the ways in which research findings are offered and reviewed in the field of literature studies.

6. To be able to better grasp the concept of spatiality and its emerging trends.

7. To help build the researcher's knowledge in the field of topophrenia - our place in the world, and how we inhabit, understand, and represent this place to others.

8. To compare and contrast each novel in its ability to contribute to the objectives of the study.

9. To critically evaluate each novel's style of narration, plot construction and linguistic mode as dictated by the city as a setting.

10. To understand how each novel contributes to the reader's interpretation and understanding of the city that is the setting, through its portrayal in the novel.

11. To be able to include the analysis of the novels into the state of knowledge on the topic.

12. To be able to highlight gaps in the existing research in the presentation of cities in novels.

13. To empower the researcher to address gaps in the existing research through new research.

\section{A SPATIAL ANALYSIS OF CITYSCAPES :}

Every attempt at a mega research has to be backed by a theoretical framework so as to interpret and validate the findings. In literature too one comes across several theories such as Marxist theory, postcolonial theory and feminist theory, among others.

This work of mega research will be supported by a spatial analysis of the cities that form a setting of the novels. Spatial literary studies, as a theory, considers the portrayal of space and place, be it as a tangible presence in real life, in fictional narratives or in those in-between spaces where fiction meets fact. When it comes to analysing the portrayal of space in literature, spatial criticism transgresses into interdisciplinary areas such as urban studies, political movements, architecture, history, behavioural sciences, social theory and of course, geography.

It was Edward Soja [64] who offered a major thrust to spatial theory with his concept of third space, taking forward the idea of heterotopias or worlds within worlds by Foucault [52] and Henri Lefebvre's triad of perceived space, conceived space and lived space [43]. The last is what Soja referred to as third space. Spatial theory attempts to analyse interdependent nature of the relationships between space, history, political developments, religious movements, value conflicts that dictate behaviour and finally their portrayal in literature. To this extent it is not only text but images such as photographs, maps, films, paintings, video games and other technical gadgets and such other aspects that are studied to get a polysensorial consideration of space in literature. Robert T. Tally Jr. [27, 34] offered a theoretical base with his erudite and in-depth study into various aspects that could take the theory forward.

A spatial criticism of the texts will analyse and explore the significance of space and place and their importance in literature and in the lives of humans, in the formation of their identities and construction of their lifestyles. The author as a flaneur is definitely an aspect of city novels that will be considered, taking motivation from works such as Dickens' The Uncommon Traveller [74] as also Trickster City: Writings from the belly of the metropolis, which is a collection of compassionate observations on life in Delhi [91].

\section{IMPLEMENTATION OF RESEARCH ACTIVITIES ACCORDING TO THE PROPOSAL:}

The proposal has the study and analysis of the portrayal of cities in selected novels. While the primary texts have to be, no doubt, studied in detail, the other approaches of learning about the history, political and geographical environment as well as the current scenarios in the cities need to be understood by taking recourse to different media such as films, theatre, online media such as social networking sites and undertaking a textual analysis of news reports, fiction such as novels and short stories, poems and travelogues. Cities are organisms that do not exist in a vacuum but keep growing and changing in tandem with the environment in which they are placed and the research activities will be conducted by taking cognisance of this fact.

\section{LIMITATIONS OF THE PROPOSAL :}

The research will be conducted through a content analysis and exploratory study of primary texts which are works of fiction, other works of fiction associated with the concept, peer-reviewed research papers and different types of non-fictional prose. 
The limitations that arise from having works of fiction as the primary text are:

The differences in the styles of writing, influence of political slants, possible predominance of religious beliefs, the impact of value systems, cultural biases and perceptions of the novelists can result in a degree of subjectivity that the researcher has to factor in, in the analysis.

The plotlines of the novels may not accommodate descriptions of several aspects of the city and these again may give rise to a lopsided perspective of the city as perceived by the researcher.

The novelists may not use the existing names of the streets and lanes, though the cultural nuances may be retained. The researcher has to be able to sift the fact from the fiction in the process of analysis.

\section{CONCLUSION :}

There is no doubt that cities that are settings of novels have the potential to transform the plot, characters, tone, language and other cultural signposts in a novel. The various aspects of life in a city offer the base from which the imagination of the writer can take off. The city provides character to the work and colours much of the ability of the reader to envision the narrative. Many works of fiction that have stood the test of time have the names of cities included in the titles themselves. We cannot deny that places are storehouses of life experiences that form a part a person's identity too and support psychological well-being. Such sentiments contribute towards the ways in which cities are planned and form the identity of the places as well. Each city offers a particular setting and it is important that novelists incorporate the significance of space and its attributes to enrich the reading experience of the reader.

\section{REFERENCES :}

[1] Scammell, G. (2020, August 05). How cities are taking centre stage as characters in novels. https://theconversation.com/how-cities-are-taking-centre-stage-as-characters-in-novels-142688

Accessed on 20-12-2021

[2] Ujang, N. (2012). Place attachment and continuity of urban place identity. Procedia-Social and Behavioral Sciences, 49(1), 156-167.

Google Scholar X

[3] Buttimer, A. (1980). Home, Reach, and the Sense of Place. In Buttimer, A., Seamon, D.(eds.). The Human Experience of Place and Space, 3(1), 166-187. Croom Helm Publishers.

Google Scholar X

[4] Mullin, K. (2016, May 25). Cities in modernist literature (Theme: capturing and creating the modern). bl.uk. https://www.bl.uk/20th-century-literature/articles/cities-in-modernist-literature Accessed on 20-12-2021

[5] Sengupta, R. (2021, February 21). How Delhi has been written over the years in novels and in stories (and essays). Scroll.in. https://scroll.in/article/987332/how-delhi-has-been-written-over-theyears-in-novels-and-in-stories-and-essays Accessed on 20-12-2021

[6] Ameel, L (2017). The city novel: Measuring referential, spatial, linguistic and temporal distances. In: Tally, R (ed.) The Routledge Handbook of Literature and Space, London: Routledge, $1(1), 233-241$.

Google Scholar 7

[7] Peraldo, E. (2017). From the city of London to the desert island: Daniel Defoe and the writing of Space and places. In: Tally, R (ed.) The Routledge Handbook of Literature and Space, London: Routledge, 1(1), 242-250.

Google Scholar X

[8] Manase, I (2017). The Speculative Fictional Mapping of Literary Johannesburg's Spaces in Beukes's Zoo City and Grey's The Mall. In: Tally, R (ed.) The Routledge Handbook of Literature and Space, London: Routledge, 1(1), 251-260. Google Scholar $X^{7}$

[9] Roy, M., \& Roy, A. G. (2017). The production of alternative global spaces: Walking in the city in Salman Rushdie's novels. GeoHumanities, 4(2), 1-14. Google Scholar X' 
[10] Mundell, M. (2018). Crafting "Literary Sense of Place": the generative work of literary placemaking. Journal of the Association for the Study of Australian Literature, 18(1), 1-17.

Google Scholar $x^{\top}$

[11] Bryden, I. (2009). Crossing the Street: Literature and Urban Space. Working with English, 5(1), 21-32.

Google Scholar X

[12] Balaa, L. (2018). Exploring Thirdspace in Nada Awar Jarrar's Unsafe Haven. Antipodes, 32(1-2), $30-47$.

Google Scholar $x^{7}$

[13] Minto, D. N. (2015). New York and Toronto Novels after Postmodernism: Explorations of the Urban by Caroline Rosenthal. Callaloo, 38(2), 401-405.

Google Scholar $X^{\nearrow}$

[14] Daniels, S., \& Rycroft, S. (1993). Mapping the modern city: Alan Sillitoe's Nottingham novels. Transactions of the Institute of British Geographers, 18(4), 460-480.

Google Scholar X'

[15] Cannon, J. (1978). The image of the city in the novels of Italo Calvino. Modern Fiction Studies, 24(1), 83-90.

Google Scholar 7

[16] Features. (2015, September 07), Imaginary places in literature that became iconic. ETimes. https://timesofindia.indiatimes.com/life-style/books/features/imaginary-places-in-literature-thatbecame-iconic/photostory/77888946.cms Accessed on 04-01-2021.

[17] Parashkevova, V. (2012). Salman Rushdie's Cities: Reconfigurational Politics and the Contemporary Urban Imagination. Bloomsbury Publishing, 1(1), 2-3.

Google Scholar $\chi^{7}$

[18] Pataki, É. (2014). This Dasht-e-Tanhaii called the planet Earth": The Metamorphosis of Space and Identity in Nadeem Aslam's" Maps for Lost Lovers. Hungarian Journal of English and American Studies (HJEAS), 20(2), 79-100.

Google Scholar $X^{7}$

[19] Morrison, T., \& Stepto, R. (1977). Intimate Things in Place: A Conversation with Toni Morrison. The Massachusetts Review, 18(3), 473-489.

Google Scholar X

[20] Day, E. (2018, May 15). The 10 best city novels. The Guardian. https://www.theguardian.com/culture/2015/may/15/the-10-best-city-novels

Accessed on 20-12-2021

[21] Walonen, M. K. (2015). Applying Geocritical Theory to the Study Abroad Learning Experience. Frontiers: The Interdisciplinary Journal of Study Abroad, 25(1), 37-46.

Google Scholar X

[22] Rosenthal, C. (2011). New York and Toronto novels after postmodernism. Camden House. 1(1), 1-30 Google Scholar $X^{\top}$

[23] Peraldo, E. (Ed.). (2016). Literature and geography: the writing of space throughout history. Cambridge Scholars Publishing, 1(1), 340-363

Google Scholar $x^{\top}$

[24] Defoe, D. (1904). A journal of the plague year. D. Estes \& Company, 9(1), 1-10.

Google Scholar X

[25] Westphal, B. (2011). Geocriticism: real and fictional spaces. Springer, 1-7.

Google Scholar $x^{\top}$

[26] Jordan, P. (2012). Place names as ingredients of space-related identity. Oslo Studies in Language, 4(2), 117-131. 
Google Scholar $\chi^{7}$

[27] Tally Jr, R. T. (Ed.). (2011). Geocritical explorations: Space, place, and mapping in literary and cultural studies. Springer, 1-4.

Google Scholar $\chi^{\top}$

[28] Al-Khafaji, A. (2018). Geocriticism: Reading Literature in the Spatial Tur. Al-Qadisiyah Journal for Humanities Sciences, 21(4), 7-16.

Google Scholar $x^{7}$

[29] Prieto, E. (2012). Literature, geography, and the postmodern poetics of place. Springer. 1-14. Google Scholar $x^{7}$

[30] Hodneland, T. E. (2019). Cities of Tomorrow-Urban Landscapes and Urban Sustainability in Marie Lu's Legend trilogy (Master's thesis, Høgskulen på Vestlandet), 70-75.

Google Scholar $x^{\top}$

[31] Prieto, E. (2011). Geocriticism, geopoetics, geophilosophy, and beyond. In Geocritical explorations, 13-27. Palgrave Macmillan, New York.

Google Scholar $x^{7}$

[32] Arias, S. (2010). Rethinking space: an outsider's view of the spatial turn. GeoJournal, 75(1), 2941.

Google Scholar $x^{7}$

[33] Finch, J. (2016). Deep Locational Criticism: Imaginative Place in Literary Research and Teaching. John Benjamins Publishing Company, 3(1), 1-57.

Google Scholar $X^{\top}$

[34] Tally Jr, R. T. (Ed.). (2016). Literary cartographies: Spatiality, representation, and narrative. Springer, 1-12.

Google Scholar $x^{7}$

[35] Gregorová, M. (2016). Searching for the Dear Green Place in Agnes Owens's Like Birds in the Wilderness. Hradec Králové Journal of Anglophone Studies, 3(1), 50-56.

Google Scholar X

[36] Moretti, F. (1999). Atlas of the European novel, 1800-1900. Verso, 4-62.

Google Scholar X

[37] Malkki, L. (1992). National geographic: The rooting of peoples and the territorialization of national identity among scholars and refugees. Cultural anthropology, 7(1), 24-44.

Google Scholar $x^{7}$

[38] Tally, R. T. (2017). Introduction: The Reassertion of Space in Literary Studies. In The Routledge Handbook of Literature and Space (pp. 1-6). Routledge.

Google Scholar X

[39] Westphal, B. (2007). Transgressivity. In Geocriticism (pp. 37-74). Palgrave Macmillan, New York.

Google Scholar ${ }^{7}$

[40] Helleland, B. (2012). Place names and identities. Oslo Studies in Language, 4(2), 95-116. Google Scholar X

[41] Chalupský, P. (2018). The imaginary landscapes of Jim Crace's Continent. Athens Journal of Philology, 5(3), 201-220.

Google Scholar ${ }^{\top}$

[42] Brace, C., \& Johns-Putra, A. (2010). Recovering inspiration in the spaces of creative writing. Transactions of the Institute of British Geographers, 35(3), 399-413.

Google Scholar $\chi^{7}$ 
[43] Gieseking, J. J., Mangold, W., Katz, C., Low, S., \& Saegert, S. (Eds.). (2014). The people, place, and space reader. Routledge, 289-293

Google Scholar ${ }^{\top}$

[44] Westphal, B. (2007). Referentiality. In Geocriticism, 75-110. Palgrave Macmillan, New York. Google Scholar $X^{7}$

[45] Malpas, J. (2009). Place and human being. Environmental and architectural phenomenology, 20(3), 19-23.

Google Scholar X

[46] Rathee, H. (2018). Exploring History and Culture: A Study of William Dalrymple's City of Djinns. IMPACT: International Journal of Research in Humanities, Arts and Literature (IMPACT: IJRHAL, 6(1), 189-192.

Google Scholar $X^{\top}$

[47] Dogra, N. (2020, June 07). Decoding A City: Common Thread That Connects 'Delhi 6', 'City Of Djinns' And Covid-19. Outlook. https://www.outlookindia.com/website/story/india-newsdecoding-a-city-common-thread-that-connects-delhi-6-city-of-djinns-and-covid-19/354313 Accessed on 28.122021

[48] Thacker, A. (2003). Moving through modernity: Space and geography in modernism. Manchester University Press, 1-64.

Google Scholar 7

[49] Malpas, J. (2018). Place and experience: A philosophical topography. Routledge, 1-30. Google Scholar X

[50] Bose, B. (2011). Cities, sexualities and modernities: A reading of Indian cinema. Thesis Eleven, 105(1), 44-52.

Google Scholar $x^{7}$

[51] Westphal, B. (2007). Elements of Geocriticism. In Geocriticism, Palgrave Macmillan, New York. l(1), 111-147.

Google Scholar 7

[52] Foucault, M., \& Miskowiec, J. (1986). Of other spaces. diacritics, 16(1), 22-27. Google Scholar $\chi^{\top}$

[53] Gin, S. L. T., \& Cacciafoco, F. P. (2021). Toponyms as a Gateway to Society. In Old World: Journal of Ancient Africa and Eurasia, 1(1), 1-18.

Google Scholar $\chi^{7}$

[54] Rossetto, T. (2014). Theorizing maps with literature. Progress in Human Geography, 38(4), 513530.

Google Scholar $\chi^{7}$

[55] Tally Jr, R. T. (2009). Melville, Mapping and Globalization: Literary Cartography in the American Baroque Writer. Bloomsbury Publishing, 1(1), 2-8. Google Scholar $X^{\top}$

[56] Howell, S. C. (1983). The meaning of place in old age. Aging and milieu: Environmental perspectives on growing old, 1(1), 97-107.

Google Scholar $x^{\top}$

[57] Hegglund, J. (2012). World views: Metageographies of modernist fiction. OUP USA, 1(1), 1-9. Google Scholar ${ }^{7}$

[58] Levy, D. W. (1978). City signs: Toward a definition of urban literature. Modern Fiction Studies, 24(1), 65-73.

Google Scholar ${ }^{7}$ 
[59] Hezam, A. M. M. (2020). The Protagonist and the City: Istanbul in Orphan Pamuk's A Strangeness in My Mind and The Museum of Innocence. Arab World English Journal for Translation \& Literary Studies, 4(3), 87-96.

Google Scholar X

[60] Nnodim, R. (2008). City, identity and dystopia: Writing Lagos in contemporary Nigerian novels. Journal of Postcolonial Writing, 44(4), 321-332.

Google Scholar $\chi^{\top}$

[61] Warf, B., \& Arias, S. (2008). Introduction: the reinsertion of space in the humanities and social sciences. In The spatial turn, 17-26. Routledge.

Google Scholar $x^{7}$

[62] Stadler, J., Mitchell, P., \& Carleton, S. (2015). Imagined landscapes: geovisualizing Australian spatial narratives. Indiana University Press, 1-27.

Google Scholar X

[63] Sanders, J. (2011). The cultural geography of early modern drama, 1620-1650. Cambridge University Press, 1-36.

Google Scholar $x^{7}$

[64] Soja, E. W. (2008). Taking space personally. In The spatial turn, 1(1), 27-51. Routledge. Google Scholar X

[65] Borden, I. (1997). Space beyond: Spatiality and the city in the writings of Georg Simmel. The Journal of Architecture, 2(4), 313-335.

Google Scholar $X^{\top}$

[66] Caquard, S. (2013). Cartography I: Mapping narrative cartography. Progress in Human Geography, 37(1), 135-144.

Google Scholar $x^{7}$

[67] Jaye, M. C., \& Watts, A. C. (Eds.). (1981). Literature \& the American Urban Experience: Essays on the City and Literature. Manchester University Press, 1-65.

Google Scholar $X^{7}$

[68] Howe, I. (1971). The city in literature. Commentary, 51(5), 61. Google Scholar $\chi^{7}$

[69] Festa-McCormick, D. (1979). The city as catalyst: a study of ten novels. Fairleigh Dickinson Univ Press, 9-15. Google Scholar 7

[70] Golimowska, K. (2016). The Post-9/11 City in Novels: Literary Remappings of New York and London. McFarland, 1(1), 1-21.

Google Scholar $X^{\top}$

[71] Ryan, M. (2014, April 22). Space. The living handbook of narratology. https://www.lhn.unihamburg.de/node/55.html Accessed on 17 January 2022

[72] Wirth-Nesher, H., \& Hana, W. N. (1996). City codes: reading the modern urban novel. Cambridge University Press, 1-30.

Google Scholar X'

[73] Wade, J. P. (1990). "Song of the City" and "Mine Boy": The 'Marxist' Novels of Peter Abrahams. Research in African Literatures, 21(3), 89-101.

Google Scholar 7

[74] Willis, M. (2003). Dickens the flânuer-London and "the uncommercial traveller". Dickens Quarterly, 20(4), 240-256.

Google Scholar $x^{7}$

[75] Kumar, P. (1990). The City in Premchand's Novels. Journal of South Asian Literature, 25(1), $67-$ 75. 
Google Scholar 7

[76] Gravano, A. J. (2011). New York City in Don DeLillo's Novels. Italian Americana, 29(2), 181189.

Google Scholar $x^{7}$

[77] Keesee, D. G. (1988). Specters of TS Eliot's City in the Novels of Charles Williams. VII: Journal of the Marion E. Wade Center, 9(1), 47-55.

Google Scholar $X^{7}$

[78] Poole, S. (1994). Street-signs: the city as context and as code in the novels of Claire Etcherelli. Studies in 20th \& 21 st Century Literature, 18(2), 189-201.

Google Scholar X

[79] Grothe, M. F. (2000). City of memory: Barcelona in the novels of Juan Marse and Eduardo Mendoza. The Johns Hopkins University, 1(1), 1-10.

Google Scholar $\chi^{\top}$

[80] Pittin-Hédon, M. O. (2007). Re-imagining the City: End of the Century Cultural Signs in the Novels of McIlvanney, Banks, Gray, Welsh, Kelman, Owens and Rankin. Modern Transformations: New Identities (from 1918), 3(1), 253-260.

Google Scholar $\chi^{7}$

[81] Rodrigues, J. (2013) Chetan Bhagat's One Night@ The Call Center: A Global Post-Modern Literature. Journal of Higher Education and Research Society, 1(1), 47-53.

Google Scholar $X^{\top}$

[82] Shahani, R. G. (1995). Polyphonous Voices in the City: Bombay's Indian-English Fiction. Economic and Political Weekly, 1(1), 1250-1254.

$\underline{\text { Google Scholar } X^{7}}$

[83] Terentowicz-Fotyga, U. (2009). Unreal city to city of referents: Urban space in contemporary London novels. Journal of Narrative Theory, 39(3), 305-329.

Google Scholar $x^{7}$

[84] Roth, I. (2010-11). Svetlana Boym argues that the city 'is an ideal crossroads between longing and estrangement, memory and freedom, nostalgia and modernity. To what extent are such intersections between place and memory foregrounded in literary representations of the city? Innervate: Leading Undergraduate Work in English Studies, 3(1), 263-269.

Google Scholar $x^{\top}$

[85] Muchemwa, K. Z. (2013). Imagining the city in Zimbabwean literature 1949 to 2009 (Doctoral dissertation, Stellenbosch: Stellenbosch University), 117-122.

Google Scholar X'

[86] Okpiliya, J. O., Eyang, A. E., \& Omagu, S. U. (2018). The City Space, Marriage and Female Friendship in Sefi Atta's Everything Good Will. Humanitaties Theoreticus, 1(1), 123-137.

Google Scholar $\chi^{\top}$

[87] Features. (2015, September 07), Imaginary places in literature that became iconic. ETimes. https://timesofindia.indiatimes.com/life-style/books/features/imaginary-places-in-literature-thatbecame-iconic/photostory/77888946.cms Accessed on 17 January 2022

[88] Wolfreys, J. (1998). Writing London: the trace of the urban text from Blake to Dickens. Springer, $1(1), 1-21$. Google Scholar X

[89] Hansen, A. (2020). Marlowe's Strange Cities. Journal of Marlowe Studies, 1(1), 55-80. Google Scholar ${ }^{7}$

[90] Chambers, C. (2016). Lahore Lahore Hai: Bapsi Sidhwa and Mohsin Hamid's City Fictions. In Postcolonial Urban Outcasts, 1(1), 125-142. Routledge.

Google Scholar $X^{\top}$ 
[91] Tabassum, A. (2010). Trickster city: Writings from the belly of the metropolis. Penguin Books India, 1(1), 131-134.

Google Scholar $x^{\top}$

[92] Mohammad, N. M. N., Saruwono, M., Said, S. Y., \& Hariri, W. A. H. W. (2013). A sense of place within the landscape in cultural settings. Procedia-Social and Behavioral Sciences, 105(1), 506512.

Google Scholar $x^{7}$

[93] Auden, W. H. (1962). The poet \& the city. The Massachusetts Review, 3(3), 449-474.

Google Scholar $x^{\top}$

[94] Qiang, Z. (2017). Translating Cities: WH Auden and 1940s Chinese Metropolis Poetry. Journal of Translation Studies, 1(2), 75-99.

Google Scholar $X$

[95] McNees, E. (2010, September). Public Transport in Woolf's City Novels: The London Omnibus. In Woolf and the City: Selected Papers from the Nineteenth Annual Conference on Virginia Woolf, 1(1), 31-39. Clemson, SC: Clemson University Press.

Google Scholar $x^{7}$

[96] Gade, D. S., \& Aithal, P. S. (2021). Smart Cities Development During and Post COVID-19 Pandemic-A Predictive Analysis. International Journal of Management, Technology and Social Sciences (IJMTS), 6(1), 189-202.

Google Scholar $X^{7}$

[97] Vincent, P., \& D’Mello, L. (2018). Changing Trends of Divorce in India: Issues \& Concerns. International Journal of Management, Technology and Social Sciences (IJMTS), 3(2), 151-157.

Google Scholar $\chi^{7}$

[98] Thomas, S. B., \& Kotian, S. (2021). Are You Happy with The Way Your Body Looks in Midlife? International Journal of Management, Technology and Social Sciences (IJMTS), 6(2), 64-74.

Google Scholar $x^{7}$

[99] Lewicka, M. (2011). On the varieties of people's relationships with places: Hummon's typology revisited. Environment and Behavior, 43(5), 676-709.

Google Scholar X

[100] Mantri, M. (2019). Bombay Novels: Some Insights in Spatial Criticism. Cambridge Scholars Publishing, 1(1), 1-7.

Google Scholar $x^{7}$ 